\title{
Rituximab for the treatment of patients with autoimmune hepatitis who are refractory or intolerant to standard therapy
}

\author{
Kelly W Burak MD MSc FRCPC ${ }^{1}$, Mark G Swain MD MSc FRCPC ${ }^{1}$, Tania Santodomino-Garzon PhD ${ }^{1}$, \\ Samuel S Lee MD FRCPC ${ }^{1}$, Stefan J Urbanski MD², Alexander I Aspinall MD PhD FRCPC ${ }^{1}$, \\ Carla S Coffin MD MSc FRCPC ${ }^{1}$, Robert P Myers MD MSc FRCPC ${ }^{1}$
}

KW Burak, MG Swain, T Santodomino-Garzon, et al. Rituximab for the treatment of patients with autoimmune hepatitis who are refractory or intolerant to standard therapy. Can J Gastroenterol 2013;27(5):273-280.

BACKGROUND: Although most patients with autoimmune hepatitis $(\mathrm{AIH})$ respond to treatment with prednisone and/or azathioprine, some patients are intolerant or refractory to standard therapy. Rituximab is an anti-CD20 monoclonal antibody that depletes B cells and has demonstrated efficacy in other autoimmune conditions.

AIMS: To evaluate the safety and efficacy of rituximab in patients with refractory AIH in an open-label, single-centre pilot study.

METHODS: Six patients with definite, biopsy-proven AIH who failed prednisone and azathioprine treatment received two infusions of rituximab $1000 \mathrm{mg}$ two weeks apart and were followed for 72 weeks.

RESULTS: Rituximab was well tolerated with no serious adverse events. By week 24, mean ( \pm SD) aspartate aminotransferase (AST) levels had significantly improved $(90.0 \pm 23.3 \mathrm{U} / \mathrm{L}$ versus $31.3 \pm 4.2 \mathrm{U} / \mathrm{L}$; $\mathrm{P}=0.03)$ and mean immunoglobulin $\mathrm{G}$ levels had fallen $(16.4 \pm 2.0 \mathrm{~g} / \mathrm{L}$ versus $11.5 \pm 1.1 \mathrm{~g} / \mathrm{L} ; \mathrm{P}=0.056)$. The prednisone dose was weaned in three of four subjects, with one subject flaring after steroid withdrawal. Inflammation grade improved in all four subjects who underwent repeat liver biopsy at week 48. Regulatory $\mathrm{T}$ cell levels examined by FoxP3 immunohistochemistry paralleled inflammatory activity and did not increase on follow-up biopsies. There was no significant change in serum chemokine or cytokine levels from baseline to week $24(\mathrm{n}=5)$, although interferon-gamma-induced protein 10 levels improved in three of five subjects.

CONCLUSIONS: Rituximab was safe, well tolerated and resulted in biochemical improvement in subjects with refractory AIH. These results support further investigation of rituximab as a treatment for AIH.

Key Words: Anti-CD20 monoclonal antibody; Azathioprine; B cell; Prednisone; Safety

\section{Le rituximab pour le traitement des patients ayant une hépatite auto-immune réfractaire ou intolérante au traitement standard}

HISTORIQUE : Même si la plupart des patients atteints d'une hépatite auto-immune (HAI) répondent au traitement à la prednisone et à l'azathioprine, prises seules ou ensemble, certains patients sont intolérants ou réfractaires au traitement standard. Le rituximab est un anticorps monoclonal anti- $\mathrm{CD}_{20}$ qui épuise les lymphocytes $\mathrm{B}$ et a une efficacité démontrée pour soigner d'autres maladies auto-immunes.

OBJECTIFS : Évaluer l'innocuité et l'efficacité du rituximab chez les patients atteints d'une HAI réfractaire dans le cadre d'un projet pilote monocentrique ouvert.

MÉTHODOLOGIE : Six patients ayant une HAI définie démontrée à la biopsie qui ne répondaient pas au traitement à la prednisone et à l'azathioprine ont reçu deux infusions de $1000 \mathrm{mg}$ de rituximab à deux semaines d'intervalle et ont été suivis pendant 72 semaines.

RÉSULTATS : Le rituximab était bien toléré et ne s'associait pas à des effets indésirables graves. À la semaine 24, les taux d'aspartate aminotransférase (AST) moyens $( \pm$ ÉT) s'étaient considérablement améliorés $(90,0 \pm 23,3 \mathrm{U} / \mathrm{L}$ par rapport à $31,3 \pm 4,2 \mathrm{U} / \mathrm{L} ; \mathrm{P}=0,03)$ et les taux d'immunoglobuline $\mathrm{G}$ moyens avaient fléchi $(16,4 \pm 2,0 \mathrm{~g} / \mathrm{L}$ par rapport à $11,5 \pm 1,1 \mathrm{~g} / \mathrm{L} ; \mathrm{P}=0,056)$. Trois des quatre sujets ont été sevrés de leur dose de prednisone, et l'un a récidivé après le retrait des stéroïdes. Le grade d'inflammation s'est amélioré chez les quatre sujets qui ont subi une nouvelle biopsie hépatique lors de la semaine 48. Les taux de lymphocytes $\mathrm{T}$ régulateurs examinés par immunohistochimie FoxP3 correspondaient à l'activité inflammatoire et n'avaient pas augmenté aux biopsies de suivi. Les chercheurs n'ont remarqué aucun changement significatif des taux de chémokine ou de cytokine sérique entre la semaine de référence et la semaine $24(\mathrm{n}=5)$, même si les taux de protéine induite par interféron gamma 10 se sont améliorés chez trois des cinq sujets.

CONCLUSIONS : Le rituximab était sécuritaire, bien toléré et suscitait une amélioration biochimique chez les sujets ayant une HAI réfractaire. Ces résultats appuient la tenue de recherches plus approfondies sur l'utilisation du rituximab pour traiter l'HAI.

side effects. Approximately $80 \%$ of patients develop cosmetic changes on prednisone, leading to discontinuation of steroids in $13 \%$ (3). AZA treatment may result in cytopenias, which may be sufficiently severe to result in treatment discontinuation in $6 \%$ of $\mathrm{AIH}$ patients (3). Patients may also develop symptoms of nausea, fever, rash or pancreatitis related to the use of AZA. Furthermore, some patients exhibit a suboptimal response to standard therapy and require alternative immunosuppression. In small uncontrolled studies, refractory $\mathrm{AIH}$ has been treated with cyclosporine (4), tacrolimus (5), 6-mercaptopurine (6), cyclophosphamide (7), methotrexate (8), budesonide (9) and mycophenolate mofetil (MMF) $(10,11)$. These alternative immunosuppressive medications are associated with multiple adverse effects, enter remission within two years, treatment is associated with multiple

${ }^{1}$ Liver Unit, Division of Gastroenterology and Hepatology, Department of Medicine; ${ }^{2}$ Department of Pathology, University of Calgary, Calgary, Alberta Correspondence: Dr Kelly W Burak, Room 6D35 Teaching, Research and Wellness Building, 3280 Hospital Drive Northwest, Calgary, Alberta T2N 426.

Telephone 403-592-5049, fax 403-592-5090, e-mail kwburak@ucalgary.ca

Received for publication December 2, 2012. Accepted December 9, 2012 
and, to date, there is no accepted standard of care for patients who experience treatment failure following standard therapy (3).

Rituximab is a genetically engineered, chimeric (murine/human) monoclonal antibody directed against the CD20 antigen on the surface of normal and malignant B cells. It was first approved to treat non-Hodgkin's lymphoma (12) and, more recently, has been approved for the treatment of rheumatoid arthritis (RA) (13). It has also demonstrated efficacy in other refractory autoimmune conditions including autoimmune hematological diseases and dermatological conditions $(14,15)$. Rituximab has also been investigated in primary biliary cirrhosis (PBC). We first reported that rituximab resulted in significant improvement in alkaline phosphatase, immunoglobulin (Ig) $\mathrm{M}$ and antimitochondrial antibody (AMA) titres in 14 subjects with PBC who were refractory to ursodeoxycholic acid (16). Subsequently, these findings were confirmed in a smaller study involving six PBC patients who demonstrated incomplete response to ursodeoxycholic acid (17). The exact mechanism by which rituximab improves these autoimmune conditions is unknown $(18,19)$. Some authors have argued that B cell depletion may lead to augmentation of Treg activity, leading to restoration of self-tolerance (20).

Our aim was to determine the safety and efficacy of rituximab in patients with $\mathrm{AIH}$ who were intolerant or refractory to therapy with prednisone and/or AZA. We hypothesized that rituximab would improve refractory AIH because this disease is characterized by B cell abnormalities including autoantibody production and increased IgG levels. Furthermore, we examined the potential impact of rituximab on the population of hepatic Tregs as a potential mechanism of action.

\section{METHODS}

\section{Inclusion criteria}

An investigator-initiated, single-centre, open-label, pilot study was conducted to evaluate the safety and efficacy of rituximab in adult subjects ( $\geq 18$ years of age) with biopsy-proven AIH who had failed treatment with prednisone and/or AZA. All subjects had definite AIH according to the revised original International AIH Group diagnostic scoring system (21). Three subjects had previously failed prednisone and/or AZA due to intolerable side effects (Table 1). Three subjects were refractory to standard therapy defined as an alanine aminotransferase (ALT) or aspartate aminotransferase (AST) level more than two times the upper limit of normal (ULN) after a minimum of six months of treatment, which included at least one month of prednisone $60 \mathrm{mg}$ daily or prednisone $30 \mathrm{mg}$ daily in combination with AZA $150 \mathrm{mg}$ daily. If ALT levels were $<2 \times$ ULN at the time of screening, a liver biopsy was required within one month of enrollment demonstrating ongoing interface hepatitis.

\section{Exclusion criteria}

Major exclusion criteria were coexisting chronic viral hepatitis, alcoholic or metabolic liver disease; history of liver cancer or transplantation; treatment with alternative immunosuppression within three months; previous rituximab or other monoclonal antibody therapy; HIV infection; recurrent or recent bacterial infections; evidence of previous tuberculosis exposure by a positive tuberculin skin test; chronic fungal infections; receipt of a live vaccine within one month; decompensated cirrhosis; significant cardiac or pulmonary disease; psychiatric disorders; malignancy within five years; history of drug or alcohol abuse within six months; and pregnancy or inability to practice adequate contraception. Laboratory exclusion criteria included albumin $<30 \mathrm{~g} / \mathrm{L}$, total bilirubin $>60 \mu \mathrm{mol} / \mathrm{L}$, international normalized ratio $>1.5$, serum creatinine $>120 \mu \mathrm{mol} / \mathrm{L}$, hemoglobin $<100 \mathrm{~g} / \mathrm{L}$, platelets $<100 \times 10^{9} / \mathrm{L}$, absolute neutrophil count $<1.5 \times 10^{9} / \mathrm{L}, \mathrm{IgG}<8.8 \mathrm{~g} / \mathrm{L}$, $\operatorname{IgM}<0.5 \mathrm{~g} / \mathrm{L}$, and AST or ALT $>10 \times \mathrm{ULN}$.

\section{Intervention}

Rituximab $1000 \mathrm{mg}$ was administered as an intravenous infusion two weeks apart on days 1 and 15 of the trial. Premedication, consisting of acetaminophen $1000 \mathrm{mg}$ and diphenhydramine $50 \mathrm{mg}$, was given by mouth 60 min before each infusion. Patients were not premedicated with corticosteroids. Patients remained on stable doses of AZA for at least three months before rituximab and throughout the follow-up period. Prednisone was continued at stable doses for at least three months before and for three months following rituximab, after which a prednisone taper was allowed if patients had entered biochemical remission (defined as normal ALT, AST, bilirubin, gammaglobulin and IgG levels).

\section{Outcome measures}

The primary outcome measure was safety, defined as a lack of infusion reactions or serious adverse events. Laboratory assessments, in addition to history and physical examination, were performed at baseline, weekly for the first month, monthly for two months and every three months thereafter for a total of 72 weeks. Adverse events were graded according to the Common Toxicity criteria. To monitor the effect of rituximab on B cell populations, flow cytometry for lymphocyte subsets was performed at weeks $0,1,2,4$ and 12, and every three months thereafter. Because circulating rituximab may bind to and interfere with flow cytometry measurement of $\mathrm{CD} 2 \mathrm{O}^{+} \mathrm{B}$ cells, the B cell surface antigen CD19 (which is similarly expressed on $\mathrm{CD}^{2} 0^{+} \mathrm{B}$ cells) was used as a surrogate marker. $\mathrm{CD} 19^{+} \mathrm{B}$ cells were reported as a percentage of total lymphocytes (normal range $3 \%$ to $21 \%$ ). Serum rituximab levels were measured in all subjects at day 29 (two weeks following the second rituximab infusion) using ELISA and human antichimeric antibody antibodies (HACA) were assessed every three months using ELISA with positive results confirmed by immunodepletion with rituximab as previously described (22).

The secondary outcome measure of the trial was efficacy, which included an assessment of change in ALT, AST, bilirubin, gammaglobulin and IgG levels, and the nine-point Fatigue Severity Scale (FSS) between baseline and week 24. Also evaluated were autoantibody titres, including antinuclear antibody (ANA) and antismooth muscle antibody (ASMA), at baseline and every three months thereafter. A repeat liver biopsy at week 48 was optional and was performed in four subjects. Liver biopsies were graded by a single hepatopathologist (SJU) according to the Batts-Ludwig scoring system (23).

\section{Immunohistochemistry}

To evaluate the impact of rituximab on Treg numbers, immunohistochemistry was performed for forkhead box P3 (Fox P3) on paired liver biopsies (four subjects), using a previously described methodology (24). For antigen retrieval, tissue sections were placed in a coplin jar filled with citric acid solution ( $\mathrm{pH} \mathrm{6.0)}$ ) and heated to $90^{\circ}$ to $100^{\circ} \mathrm{C}$ for $30 \mathrm{~min}$. Endogenous alkaline phosphatase activity was blocked using levamisole and endogenous biotin binding was blocked using an avidin/ biotin blocking kit (Vector Laboratories, USA), followed by staining with mouse antihuman FoxP3 antibody (236A/E7, Abcam, USA). The bound antibody was detected by the alkaline phosphatase-labelled avidin-biotin complex method and VECTOR Red (Vector Laboratories, USA) was used as a substrate for colour development. Sections were then counterstained with Gills II hematoxylin (1:40 dilution). Sections were examined using a bright-field microscope.

\section{Serum cytokine/chemokine measurements}

Five subjects also consented to a substudy designed as an exploratory analysis evaluating the impact of rituximab on serum cytokine and chemokine levels. Baseline and week 24 serum samples were evaluated using the human cytokine/chemokine 20-plex assay by multiplexing LASER bead technology (Eve Technologies, Canada).

\section{Ethical considerations}

Health Canada and the Research Ethics Board at the University of Calgary (Calgary, Alberta) approved the research protocol in December 2004, and all subjects provided informed consent. The study sponsor, Genentech Inc (South San Francisco, USA), provided the study drug, financial support for the study and performed rituximab level and HACA studies. However, the authors were otherwise solely 
TABLE 1

Baseline characteristics of subjects with autoimmune hepatitis (AlH) who were refractory or intolerant to prednisone and/or azathioprine (AZA)

\begin{tabular}{|c|c|c|c|c|c|c|c|c|c|}
\hline \multirow[b]{2}{*}{ Subject } & \multirow{2}{*}{$\begin{array}{l}\text { Age, } \\
\text { years }\end{array}$} & \multirow[b]{2}{*}{ Sex } & \multicolumn{2}{|c|}{ Biopsy } & \multirow[b]{2}{*}{ AlH score* } & \multirow{2}{*}{$\begin{array}{l}\text { Duration of } \\
\text { AlH, months }\end{array}$} & \multirow{2}{*}{$\begin{array}{c}\text { Prednisone, } \\
\text { mg }\end{array}$} & \multirow[b]{2}{*}{$\mathrm{AZA}, \mathrm{mg}$} & \multirow[b]{2}{*}{ Comments } \\
\hline & & & Grade* & Stage* $^{*}$ & & & & & \\
\hline 1 & 28 & Female & 3 & 2 & 22 & 34 & 0 & 250 & Intolerant to prednisone (weight gain) \\
\hline 2 & 29 & Male & 2 & 1 & 18 & 19 & 10 & 200 & Refractory to prednisone $+A Z A$ \\
\hline 3 & 59 & Female & 4 & 1 & 24 & 10 & 0 & 0 & Intolerant to prednisone (headaches) + AZA (nausea) \\
\hline $4^{\dagger}$ & 34 & Male & 2 & 3 & 19 & 16 & 30 & 0 & Intolerant to AZA (nausea) + MMF (nausea) \\
\hline 5 & 69 & Female & 3 & 3 & 18 & 93 & 15 & 100 & Refractory to prednisone + AZA \\
\hline $6^{\dagger}$ & 25 & Male & 3 & 3 & 20 & 28 & 20 & 100 & Refractory to prednisone $+\mathrm{AZA}+\mathrm{MMF}$ \\
\hline
\end{tabular}

*Biopsy grade and stage (according to Batts-Ludwig) and AlH score (according to the Revised Original Scoring System of the International Autoimmune Hepatitis Group) are at the time of diagnosis. The age, duration of AlH (in months), and dose of prednisone and AZA are at the time of study enrollment; ${ }^{\dagger}$ These subjects had also previously failed mycophenolate mofetil (MMF) therapy

responsible for conducting and reporting of the present investigatorinitiated study.

\section{Statistical considerations}

No formal sample size calculation was performed because the present analysis was a pilot study. Recruitment was slow due to the singlecentre nature of the study; AIH is relatively uncommon; and AIH is usually responsive to standard therapy. The first patient was enrolled in March 2006 and recruitment was halted in May 2008. Parameters were described as mean $\pm \mathrm{SE}$ and were compared at baseline and follow-up time points using paired $t$ tests.

\section{RESULTS}

The flow of subjects through the clinical trial is outlined in Figure 1. Baseline characteristics of enrolled subjects are shown in Table 1.

\section{Primary outcome - safety}

Rituximab was very well tolerated and no patients experienced infusion reactions or serious adverse events during the 72 weeks of follow-up. Subject 1 experienced a mild, unilateral conjunctivitis and a possible dental abscess 11 weeks following rituximab therapy that resolved with outpatient oral antibiotics. There were no other infectious complications during the study period. Rituximab did not significantly change hematological parameters (Table 2). Although IgG (Figure 2C) and gammaglobulin levels decreased in all subjects, no patients developed hypogammaglobulinemia. At week 46, subject 2 presented with jaundice (bilirubin $69 \mu \mathrm{mol} / \mathrm{L}$ ) and ALT $592 \mathrm{U} / \mathrm{L}$ (Figure 2B); however, this was believed to represent a flare of his $\mathrm{AIH}$ following discontinuation of prednisone at week 24. After reintroducing prednisone $20 \mathrm{mg}$ daily, his bilirubin and IgG levels normalized within four weeks, his ALT level normalized within 10 weeks and prednisone was tapered to $10 \mathrm{mg}$ daily by the end of the study (Figure 3). Interestingly, at day 29, he was the only subject with rituximab levels that were below the level of detection $(<0.05 \mu \mathrm{mol} / \mathrm{L})$ whereas all other subjects had measurable levels ranging from $48.9 \mu \mathrm{mol} / \mathrm{L}$ to $114 \mu \mathrm{mol} / \mathrm{L}$ at this time point.

Rituximab resulted in a rapid depletion of B cells, and this effect was maintained throughout the 72 weeks in five of the six subjects (Figure 2A). Only subject 3, who could not tolerate prednisone and $\mathrm{AZA}$, had $\mathrm{CD} 19^{+} \mathrm{B}$ cells return to within the normal range at week 24 . She was also the only subject to develop HACA. Despite the development of HACA and return of normal B cell levels at week 24, this subject maintained a remission through the study period.

Secondary outcome - efficacy

The depletion of $\mathrm{B}$ cells was associated with a rapid improvement in liver biochemistry by week 12 in all subjects (Figure 2B), with the improvement in AST reaching statistical significance by week 24 (Table 2). By week 24, IgG and gammaglobulin levels trended downward (Table 2). Two subjects demonstrated a decrease in ANA titres and one became ANA negative following rituximab therapy. Three subjects lost detectable ASMA titres during the study period (Table 3). Fatigue, as

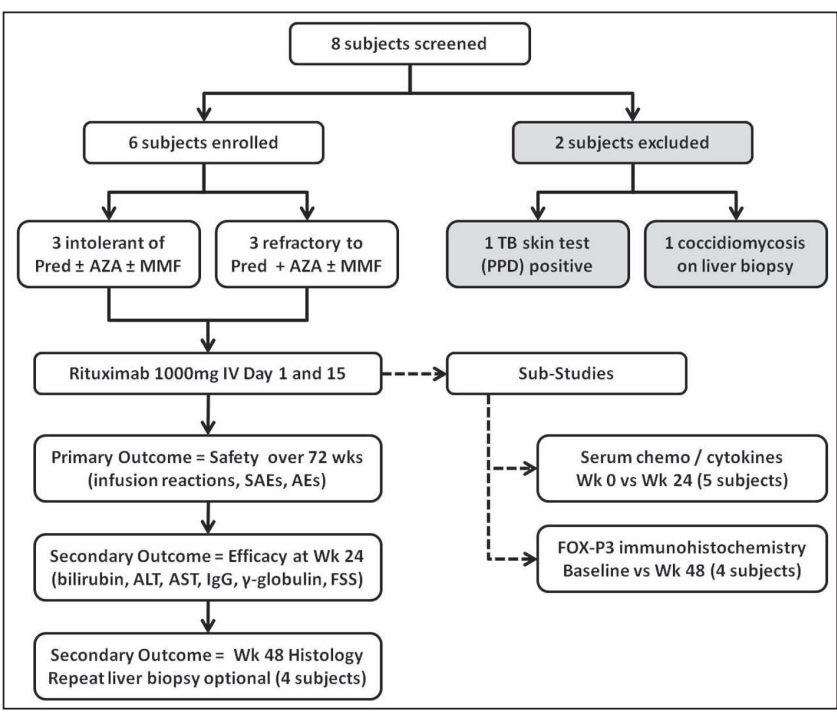

Figure 1) Overview of subject flow through the clinical trial. AEs Adverse events; ALT Alanine aminotransferase; AST Aspartate aminotransferase; AZA Azathioprine; FSS Fatigue Severity Scale; IgG Immunoglobulin G; IV Intravenous; MMF Mycophenolate mofetil; PPD Purified protein derivative; Pred Prednisone; SAEs Serious AEs; TB Tuberculosis; Wk(s) Week(s)

measured by the nine-point FSS, was highly variable among all patients (Figure 2D) and did not significantly change by week 24 (Table 2).

Once patients had entered a remission, prednisone doses were tapered at the discretion of the supervising physician in three of four subjects taking corticosteroids during the study (Figure 3). As described above, the one subject who was taken off prednisone at week 24 experienced a flare of $\mathrm{AIH}$ at week 46, which temporarily required a higher dose of prednisone to control his disease. At the time of the flare, his $\mathrm{CD} 19^{+} \mathrm{B}$ cell levels remained low.

Repeat liver biopsies were performed in four subjects at week 48 . Subjects 1 and 6 demonstrated an ALT level $<2 \times$ ULN at the time of screening and, therefore, underwent a repeat liver biopsy before study enrollment. In these patients, the follow-up biopsies demonstrated improved inflammation from grade 2 to grade 1 , but there was no difference in fibrosis stage (Figure 4). Subjects 4 and 5 did not undergo biopsies at study enrollment and, therefore, biopsies at the time of diagnosis were compared with the week-48 biopsies. In these patients, both the grade of inflammation and stage of fibrosis improved (Figure 4).

\section{Substudies}

To evaluate Treg cells, FoxP3 immunohistochemistry was performed on the four subjects with paired liver biopsies, and Figure 5 is a representative example from subject 5. Colocalization studies (Figure 5A) demonstrated that a significant proportion of lymphocytes were Tregs at the time of diagnosis. Qualitatively, the number of Tregs paralleled the total number of lymphocytes on both the baseline (Figure 5B) and 
TABLE 2

Biochemical, clinical and hematological response in subjects treated with rituximab $(n=6)$

\begin{tabular}{|c|c|c|c|c|c|c|c|}
\hline \multirow[b]{2}{*}{ Parameter (normal range) } & \multicolumn{7}{|c|}{ Week } \\
\hline & 0 & 12 & 24 & 36 & 48 & 60 & 72 \\
\hline Total bilirubin (<22 $\mu \mathrm{mol} / \mathrm{L})$ & $16.8 \pm 4.0$ & $12.2 \pm 3.3$ & $13.7 \pm 3.9 ; P=0.584$ & $15.3 \pm 4.8$ & $19.3 \pm 6.3$ & $16.8 \pm 5.9$ & $19.8 \pm 9.1$ \\
\hline Albumin (35 g/L-50 g/L) & $37.6 \pm 1.2$ & $39.3 \pm 1.8$ & $40.3 \pm 1.7 ; P=0.637$ & $39.3 \pm 1.1$ & $38.0 \pm 1.5$ & $38.8 \pm 2.2$ & $40.0 \pm 1.8$ \\
\hline ALT (M<60 U/L, F<40 U/L) & $122.5 \pm 39.4$ & $41.3 \pm 7.3$ & $39.0 \pm 10.6 ; P=0.068$ & $40.7 \pm 11.7$ & $118.3 \pm 80.9$ & $35.3 \pm 14.1$ & $53.7 \pm 30.4$ \\
\hline AST (M<40 U/L, F<32 U/L) & $90 \pm 23.3$ & $37.2 \pm 5.3$ & $31.3 \pm 4.2 ; P=0.032$ & $37.2 \pm 3.6$ & $80.7 \pm 43.9$ & $31 \pm 5.1$ & $37.5 \pm 11.6$ \\
\hline Gammaglobulin (3 g/L-13 g/L) & $13.4 \pm 1.8$ & $10.6 \pm 1.1$ & $9.7 \pm 0.9 ; P=0.097$ & $7.9 \pm 1.3$ & $8.1 \pm 0.7$ & $10.5 \pm 1.5$ & $9.8 \pm 1.2$ \\
\hline $\operatorname{lgG}(6.8 \mathrm{~g} / \mathrm{L}-18.0 \mathrm{~g} / \mathrm{L})$ & $16.4 \pm 2.0$ & $12.7 \pm 1.1$ & $11.4 \pm 1.1 ; P=0.056$ & $11.6 \pm 0.9$ & $13.7 \pm 2.3$ & $12.6 \pm 1.4$ & $11.5 \pm 1.2$ \\
\hline $\operatorname{lgA}(0.6 \mathrm{~g} / \mathrm{L}-4.2 \mathrm{~g} / \mathrm{L})$ & $2.4 \pm 0.7$ & $2.2 \pm 0.6$ & $2.1 \pm 0.6 ; P=0.937$ & $2.0 \pm 0.5$ & $2.2 \pm 0.5$ & $2.1 \pm 0.5$ & $2.1 \pm 0.5$ \\
\hline $\operatorname{lgM}(0.4$ g/L-3.0 g/L) & $1.9 \pm 0.8$ & $1.2 \pm 0.5$ & $1.1 \pm 0.4 ; P=0.842$ & $1.0 \pm 0.4$ & $1.4 \pm 0.7$ & $1.3 \pm 0.7$ & $1.3 \pm 0.7$ \\
\hline FSS (range 1-7) & $4.1 \pm 2.4$ & $3.7 \pm 0.5$ & $3.1 \pm 0.8 ; P=0.650$ & $3.5 \pm 1.0$ & $3.7 \pm 0.8$ & $3.3 \pm 0.8$ & $3.6 \pm 0.8$ \\
\hline Hemoglobin (120 g/L-180 g/L) & $144 \pm 4.7$ & $146 \pm 3.5$ & $146 \pm 4.5 ; P=0.690$ & $146 \pm 5.6$ & $145 \pm 4.7$ & $147 \pm 6.6$ & $147 \pm 5.9$ \\
\hline Lymphocytes $\left(0.5 \times 10^{9} / \mathrm{L}-3.3 \times 10^{9} / \mathrm{L}\right)$ & $1.6 \pm 0.3$ & $1.7 \pm 0.4$ & $1.2 \pm 0.2 ; P=0.259$ & $1.2 \pm 0.3$ & $1.2 \pm 0.1$ & $1.4 \pm 0.2$ & $1.3 \pm 0.2$ \\
\hline $\begin{array}{l}\text { CD19+ B cells } \\
\left(0.05 \times 10^{9} / \mathrm{L}-0.47 \times 10^{9} / \mathrm{L}\right)\end{array}$ & $0.23 \pm 0.08$ & $\begin{array}{c}0.00 \pm 0.00 \\
P=0.027\end{array}$ & $0.02 \pm 0.01 ; P=0.324$ & $0.02 \pm 0.02$ & $0.03 \pm 0.03$ & $0.03 \pm 0.02$ & $0.05 \pm 0.04$ \\
\hline
\end{tabular}

Data presented as mean \pm SE; paired t tests were performed to compare change in parameters between baseline and week 24 (time point for efficacy analysis). Bolded values indicate statistically significant results (ie, P<0.05). ALP Alkaline phosphatase; ALT Alanine aminotransferase; AST Aspartate aminotransferase; GGT Gamma-glutamyl transpeptidase; Ig Immunoglobulin; INR International normalized ratio of prothrombin time; F Female; FSS Fatigue Severity Scale; M Male; WBC White blood cell count
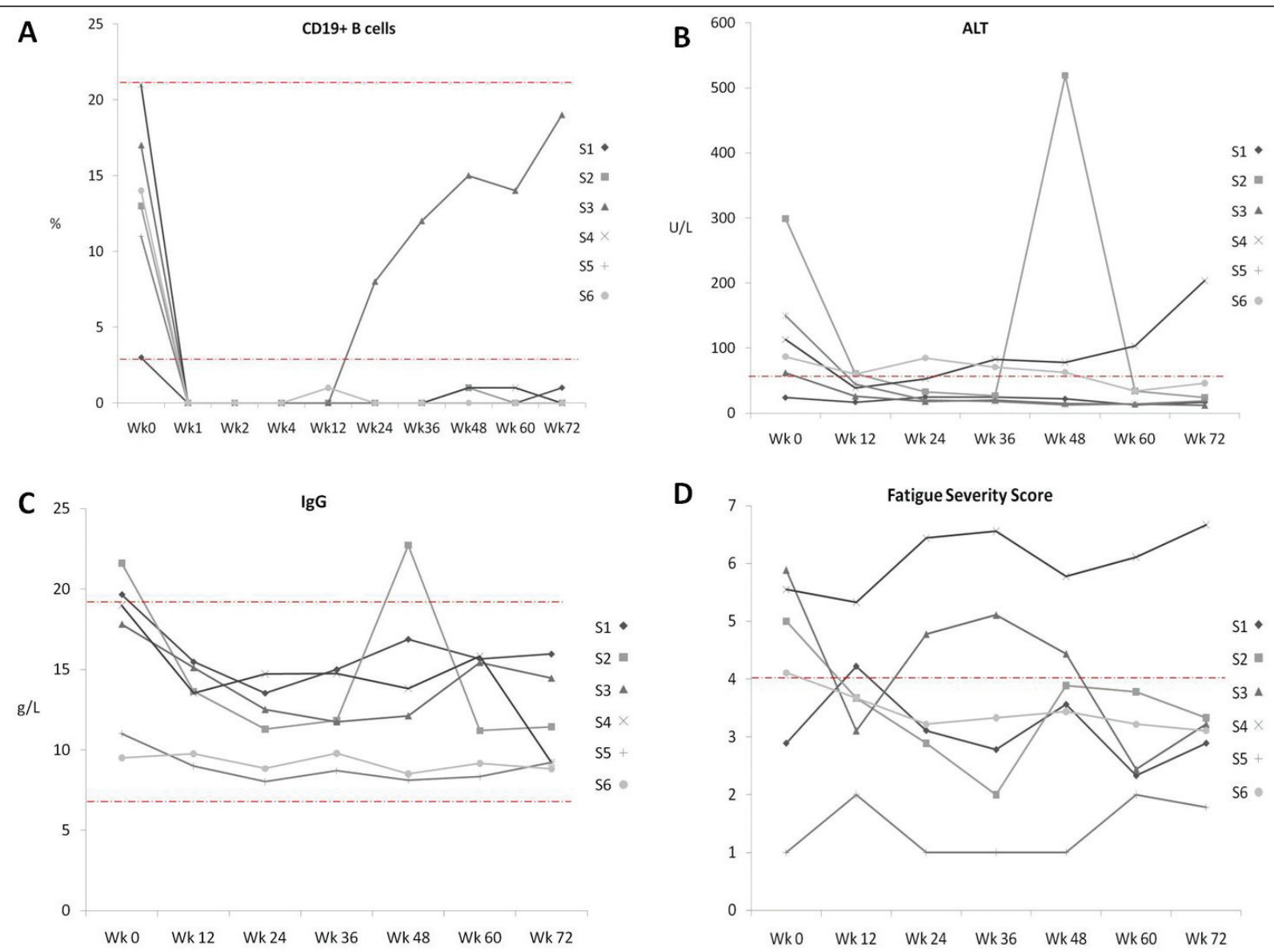

Figure 2) Safety, biochemical and clinical outcomes of patients receiving rituximab for refractory autoimmune hepatitis. CD19-positive B cells (A) became undetectable in all patients and returned to the normal range in only one subject. By week (Wk) 12, alanine aminotransferase (ALT) levels (B) normalized in all subjects. One subject subsequently experienced a flare at Wk 46 after he was withdrawn from steroids at Wk 24. Immunoglobulin G (IgG) levels (C) fell in all subjects by Wk 24, but no patient developed hypogammaglobulinemia. Fatigue measured according to the Fatigue Severity Scale (D) varied significantly among the patients. Dashed lines represent the normal value range. S Subject 


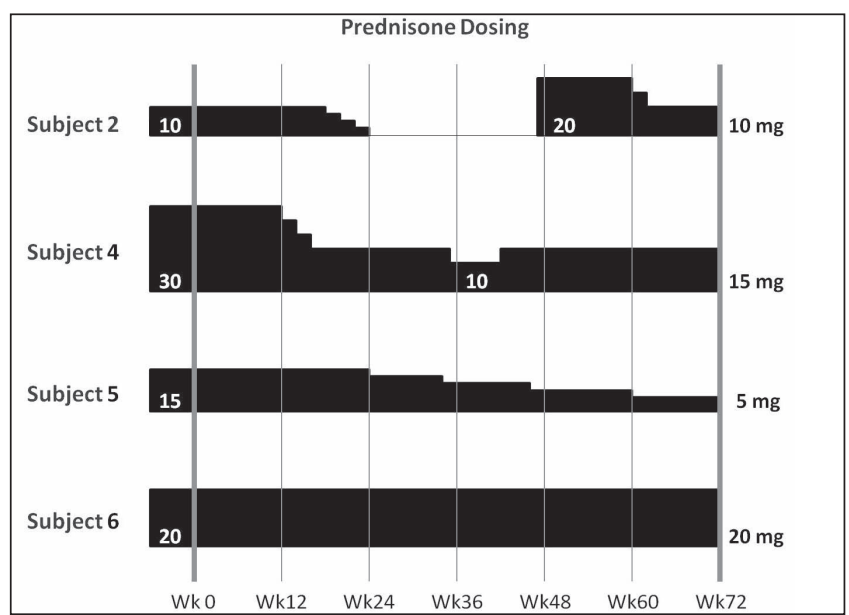

Figure 3) Illustration of prednisone dose adjustments during the clinical study. Subject 2 was quickly weaned from prednisone but required reintroduction of steroids to treat a flare of his autoimmune hepatitis. Subjects 4 and 5 were able to decrease their prednisone dose while subject 6 remained on stable dose of prednisone throughout the study period. Wk Week

follow-up biopsies (Figure 5C). Although it was hypothesized that Treg numbers may proportionally increase following rituximab therapy, this was not apparent on any of the follow-up biopsies (data not shown).

Paired serum samples were available from five subjects to examine the impact of rituximab on serum chemokines and cytokines. None of the 20 chemokines or cytokines demonstrated a significant change from baseline to week 24 (Table 4). However, three subjects who all demonstrated interferon gamma-induced protein 10 (IP-10) levels $>1000 \mathrm{pg} / \mathrm{mL}$ at baseline showed dramatic decreases in IP-10 following rituximab (Figure 6). These same three subjects had the highest ALT levels at baseline (Figure 2B) and, therefore, also experienced the greatest improvement in ALT levels following rituximab therapy.

\section{DISCUSSION}

In the present study, we demonstrated the safety and potential efficacy of selective $\mathrm{B}$ cell depletion using the monoclonal anti-CD20 antibody rituximab in patients with AIH who were refractory or intolerant to standard therapy with prednisone and AZA. Most importantly, we demonstrated that rituximab is safe to use in this population. Despite the lack of steroid premedication, no patients developed infusion reactions and we identified only one minor infectious complication.

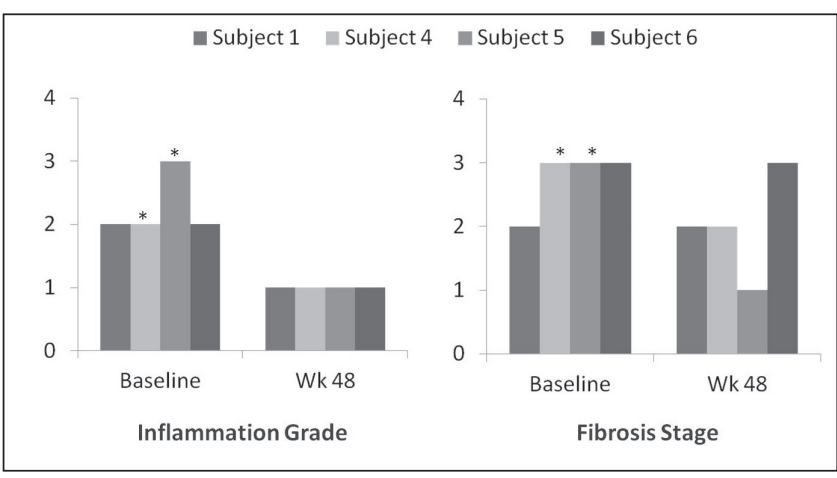

Figure 4) Comparison of liver histology at baseline and at week (Wk) 48 after rituximab. Baseline biopsies were from the time of diagnosis in subjects 4 and 5 (asterisk) and from time of study enrollment in subjects 1 and 6

Furthermore, rituximab improved liver biochemistry and decreased serum IgG levels, but no patient developed hypogammaglobulinemia. In our subjects, ANA titres decreased in two subjects and became negative in one, while three of four subjects lost their ASMA titres. Rituximab has been previously shown to have differential effects on serum autoantibodies in various autoimmune diseases (19).

The impact of rituximab on fatigue was evaluated using the nine-point FSS. At baseline, five of the six subjects had an FSS score $\geq 4$ (Figure 2D), which has been proposed as the threshold for the diagnosis of clinically relevant fatigue (25). Although interpretation of a subjective symptom such as fatigue must be viewed with some skepticism in an openlabel study, it is interesting to note that by the end of the study period only one subject continued to have an FSS score $>4$.

Although we had a difficult-to-treat population, we were able to taper the prednisone dosage during the follow-up period in three of four subjects taking steroids. However, it is important to recognize that tapering of steroids was not standardized. After subject 2 experienced a flare of AIH following withdrawal of prednisone, steroid tapers were subsequently conducted more slowly and no other patients were completely removed from prednisone during the study period.

$B$ cells remained depleted in five of the six subjects throughout the follow-up period. The only subject to demonstrate a return of their B cells was also the only subject to develop HACA. Without concurrent immunosuppression, she may have been at increased risk of developing HACA. A recent retrospective analysis in inflammatory bowel disease patients receiving infliximab found that HACA were twice as likely to form if patients were without concurrent immunosuppressant therapy

TABLE 3

Antinuclear antibody (ANA) and antismooth muscle antibody (ASMA) titres in subjects treated with rituximab ( $\mathrm{n}=6$ )

\begin{tabular}{|c|c|c|c|c|c|c|c|}
\hline \multirow[b]{2}{*}{ Subject } & \multicolumn{7}{|c|}{ ANA titres } \\
\hline & Week 0 & Week 12 & Week24 & Week 36 & Week 48 & Week 60 & Week 72 \\
\hline 1 & $1: 160$ & $1: 160$ & $1: 80$ & $1: 160$ & $1: 80$ & $1: 80$ & $1: 80$ \\
\hline 2 & Negative & Negative & Negative & Negative & Negative & Negative & Negative \\
\hline 3 & Negative & Negative & Negative & Negative & Negative & Negative & Negative \\
\hline 4 & $1: 640$ & $1: 640$ & $1: 640$ & $1: 320$ & $1: 320$ & $1: 160$ & $1: 160$ \\
\hline 5 & $1: 320$ & $1: 640$ & $1: 320$ & $1: 320$ & $1: 640$ & $1: 640$ & $1: 320$ \\
\hline \multirow[t]{2}{*}{6} & $1: 80$ & $1: 80$ & $1: 80$ & Negative & Negative & Negative & Negative \\
\hline & \multicolumn{7}{|c|}{ ASMA titres } \\
\hline Subject & Week 0 & Week 12 & Week 24 & Week 36 & Week 48 & Week 60 & Week 72 \\
\hline 1 & $1: 80$ & $1: 80$ & $1: 40$ & $1: 40$ & $1: 40$ & $1: 80$ & $1: 80$ \\
\hline 2 & $1: 20$ & Negative & Negative & Negative & Negative & Negative & Negative \\
\hline 3 & $1: 20$ & Negative & Negative & Negative & Negative & Negative & Negative \\
\hline 4 & $1: 80$ & $1: 20$ & $1: 20$ & $1: 20$ & Negative & Negative & Negative \\
\hline 5 & Negative & Negative & Negative & Negative & Negative & Negative & Negative \\
\hline 6 & Negative & Negative & Negative & Negative & Negative & Negative & Negative \\
\hline
\end{tabular}

The ANA titres decreased in two subjects and became negative in one subject. The ASMA titres became negative in three subjects 


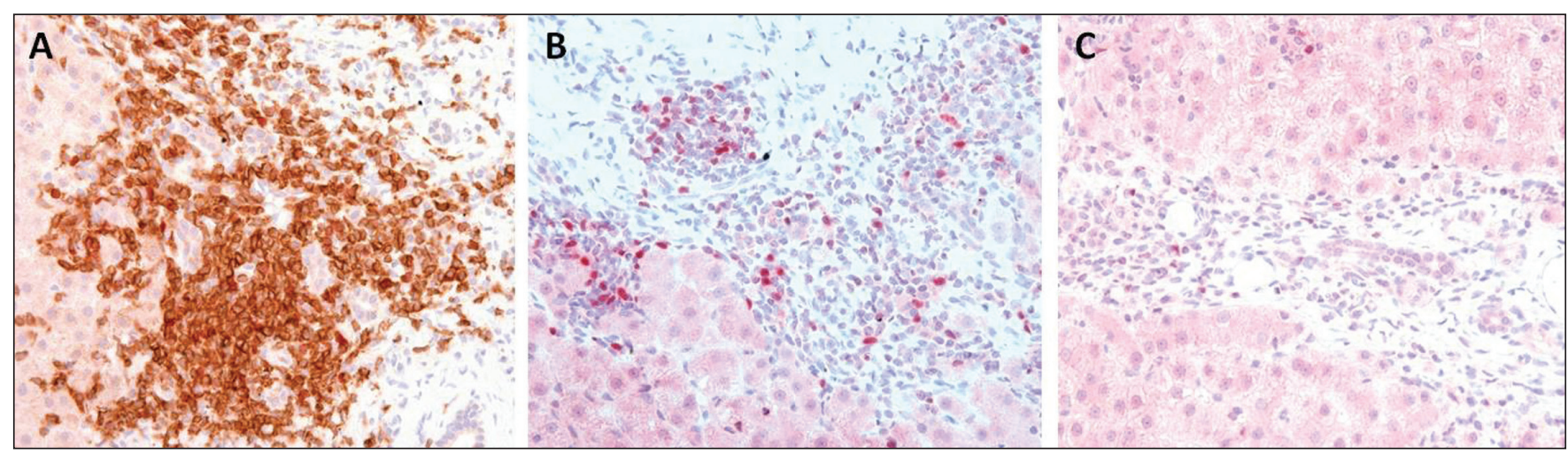

Figure 5) Immunohistochemistry performed on liver biopsies from subject 5. Baseline liver biopsy (original magnification $\times 40)$ from time of diagnosis (A) demonstrates that many of the lymphocytes (CD3-positive brown staining) are, in fact, regulatory $T$ lymphocytes (FoxP3-positive red staining). Immunohistochemistry with FoxP3 positive (red stain) and a hemotoxylin counterstain (original magnification $\times 40)$ at baseline $(\mathbf{B})$ and at week 48 following rituximab $(\mathrm{C})$ demonstrated that the numbers of regulatory $T$ lymphocytes paralleled improved inflammatory activity following treatment and did not increase in numbers after rituximab

\begin{tabular}{|c|c|c|c|}
\hline \multirow{2}{*}{$\begin{array}{l}\text { Chemo/cytokine, } \\
\mathrm{pg} / \mathrm{mL}\end{array}$} & \multicolumn{2}{|c|}{ Week } & \multirow[b]{2}{*}{$\mathbf{P}$} \\
\hline & 0 & 24 & \\
\hline Epidermal growth factor & $70.2 \pm 16.5$ & $71.5 \pm 13.0$ & 0.905 \\
\hline Eotaxin & $189.6 \pm 51.2$ & $201.3 \pm 44.3$ & 0.664 \\
\hline Interferon-gamma & $37.0 \pm 15.2$ & $36.3 \pm 18.3$ & 0.935 \\
\hline Interleukin-2 & $2.0 \pm 0.7$ & $2.5 \pm 0.8$ & 0.636 \\
\hline Interleukin-2 receptor $\alpha$ & $231.7 \pm 156.5$ & $193.0 \pm 139.2$ & 0.193 \\
\hline Interleukin-4 & $24.5 \pm 21.8$ & $56.0 \pm 50.7$ & 0.376 \\
\hline Interleukin-5 & $4.3 \pm 3.8$ & $2.4 \pm 2.01$ & 0.377 \\
\hline Interleukin-6 & $88.0 \pm 78.8$ & $76.8 \pm 68.7$ & 0.371 \\
\hline Interleukin-7 & $38.4 \pm 32.5$ & $19.3 \pm 14.5$ & 0.387 \\
\hline Interleukin-10 & $129.8 \pm 93.4$ & $61.5 \pm 53.8$ & 0.211 \\
\hline Interleukin-12 p40 & $1.5 \pm 0.4$ & $3.5 \pm 2.0$ & 0.430 \\
\hline Interleukin-12 p70 & $211.9 \pm 192.3$ & $236.7 \pm 215.3$ & 0.379 \\
\hline Interleukin-13 & $133.9 \pm 116.8$ & $90.4 \pm 69.6$ & 0.464 \\
\hline Interleukin-15 & $2.8 \pm 0.6$ & $2.6 \pm 0.7$ & 0.286 \\
\hline Interleukin-17 & $7.8 \pm 2.9$ & $11.8 \pm 5.9$ & 0.341 \\
\hline IP-10 & $1414.4 \pm 486.6$ & $434.7 \pm 34.3$ & 0.132 \\
\hline MCP-1 & $1021.9 \pm 221.0$ & $875.9 \pm 178.8$ & 0.256 \\
\hline MDC & $1882.1 \pm 346.8$ & $2008.0 \pm 402.6$ & 0.621 \\
\hline CD40 ligand & $21,030.0 \pm 4054.3$ & $24,112.1 \pm 5438.1$ & 0.327 \\
\hline Tumour necrosis factor- $\alpha$ & $5.2 \pm 1.4$ & $4.1 \pm 1.5$ & 0.204 \\
\hline
\end{tabular}

Data presented as mean \pm SE unless otherwise indicated. IP-10 Interferon gamma-induced protein 10; MCP-1 Monocyte chemotactic protein 1; MDC Macrophage-derived chemokines; p40 $40 \mathrm{kDa}$ subunit of interleukin 12; p70 $70 \mathrm{kDa}$ subunit of interleukin 12

(26). Despite a return of her B cells, this subject remained in remission throughout the follow-up period. Conversely, when subject 2 developed a flare of AIH, after withdrawal from steroids, his peripheral B cells remained depleted. Other authors have suggested that monitoring rituximab and B cell levels remains of uncertain clinical benefit (18).

A detailed pharmacokinetic analysis following intravenous rituximab $1000 \mathrm{mg}$ at day 1 and 15 in 121 RA subjects found B cells returned in $36 \%$ by week 48 , with only $8 \%$ having prolonged B cell depletion two years after rituximab (18). The B cell depletion pattern noted in the majority of our AIH patients raises the possibility that the pharmacokinetics, or effects of rituximab therapy on circulating $B$ cells, may be more prolonged in patients with chronic liver disease. However, it is important to note that clinical response in RA patients was not predicted by rituximab pharmacokinetics and return of peripheral B cells did not correlate with durability of response (18). No safety

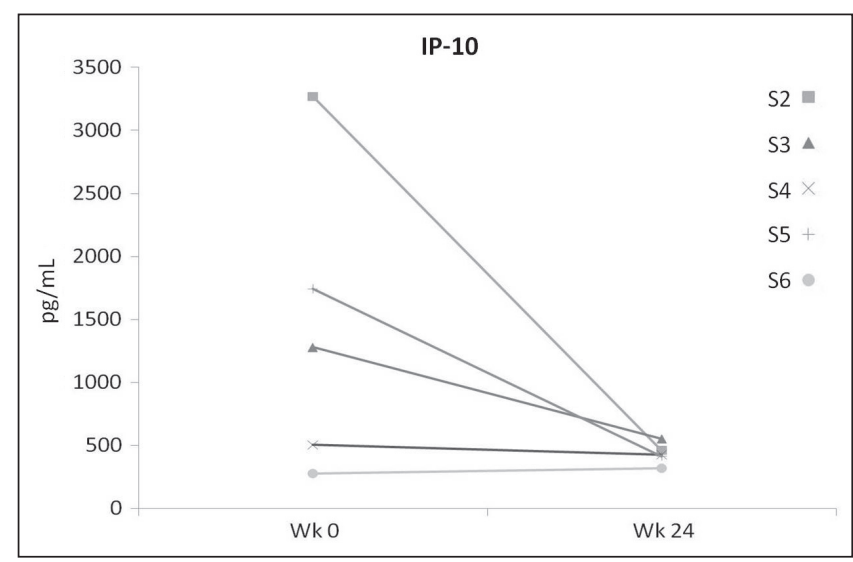

Figure 6) Interferon gamma-induced protein 10 (IP-10) levels decreased dramatically following rituximab in three of the five subjects (S) tested. Wk Week

signal was apparent in the 10 RA subjects with prolonged B cell depletion beyond two years (18) and, similarly, no subject in our study experienced any major infectious complications during the 72 weeks of observation.

There are three case reports in the published literature using rituximab to treat other conditions in patients with coexisting $\mathrm{AIH}$. In these cases, the $\mathrm{AIH}$ improved after administration of rituximab to treat refractory immune thrombocytopenia (27), cryoglobulinemiainduced membranoproliferative glomerulonephritis (28) and marginal zone B cell lymphoma (29). However, the exact mechanisms by which rituximab improve autoimmune diseases remains unknown.

$\mathrm{B}$ cells have many effector functions relevant to autoimmune disease including the production of autoantibodies, the ability to present autoantigens and costimulate $\mathrm{T}$ cells and involvement in the process of neo-organogenesis (19). However, rituximab-induced B cell depletion may also have potential effects on $\mathrm{T}$ cells that are directly relevant to autoimmune diseases (20). Defects in both hepatic regulatory $\mathrm{T}$ cell numbers and suppressive function have been implicated in the development and propagation of liver inflammation in $\mathrm{AIH}(30,31)$. Moreover, rituximab has resulted in an increase in tissue and/or circulating Treg numbers in some autoimmune diseases, and this has been suggested as a possible mechanism of action (32). Specifically, increases in Tregs have been reported following rituximab therapy in immune thrombocytopenia (33), lupus nephritis (34) and PBC (17). However, this hypothesis remains controversial and similar results have not been replicated in RA patients receiving rituximab (35). 
As has been previously reported (36), FoxP3-positive lymphocytes (ie, Tregs) were readily observed within the inflammatory infiltrate of our baseline liver biopsies. Furthermore, 48 weeks after rituximab therapy, the numbers of FoxP3-positive lymphocyte levels were strikingly reduced, appearing to parallel rituximab-induced decreases in hepatic inflammation. These observations support the suggestion that hepatic Treg numbers are elevated in $\mathrm{AIH}$, paralleling the degree of liver inflammatory cell infiltration, and that rituximab therapy results in a reduction in liver inflammation that is coupled with an associated decrease in Treg numbers.

IP-10 (also known as CXCL10) is an interferon-inducible chemokine that has been implicated as a potential marker of hepatic inflammation and fibrosis (37). Specifically, IP-10 levels are apparent at very high levels in patients with hepatitis $\mathrm{C}$ and $\mathrm{AIH}(38,39)$. In $\mathrm{AIH}$ patients, hepatocytes robustly express IP-10 and hepatic IP-10 levels correlate with serum ALT levels (39). Importantly, successful treatment of AIH with prednisone has been associated with a normalization of serum IP-10 levels (38). Rituximab therapy resulted in a striking reduction in serum IP-10 levels in all three subjects with elevated baseline levels. These same three subjects demonstrated the highest ALT levels at baseline and, therefore, also had the greatest improvement in ALT levels following rituximab therapy. IP-10 is, therefore, a potentially useful serum marker of hepatic inflammation and response to therapy in AIH patients.

Our study was limited by its small sample size and open-label design. Unfortunately, complete data were not available for all patients to carefully examine the pharmacokinetics of rituximab in this population of patients with chronic liver disease. The steroid-sparing effects demonstrated must be viewed with caution because we did not have a standardized protocol for tapering prednisone once patients entered remission. Similarly, the impact of rituximab on liver histology remains uncertain due to lack of paired biopsies in all patients. Despite these limitations, we believe that our preliminary observations support the further investigation of rituximab as a potential therapy in $\mathrm{AIH}$.

\section{REFERENCES}

1. Czaja AJ, Freese DK. Diagnosis and treatment of autoimmune hepatitis. Hepatology 2002;36:479-97.

2. Longhi MS, Ma Y, Mieli-Vergani G, Vergani D. Aetiopathogenesis of autoimmune hepatitis. J Autoimmun 2010;34:7-14.

3. Manns MP, Czaja AJ, Gorham JD, et al. Diagnosis and management of autoimmune hepatitis. Hepatology 2010;51:2193-213.

4. Sherman KE, Narkewicz M, Pinto PC. Cyclosporine in the management of corticosteroid-resistant type I autoimmune chronic active hepatitis. J Hepatol 1994;21:1040-7.

5. Van Thiel DH, Wright H, Carroll P, et al. Tacrolimus: A potential new treatment for autoimmune chronic active hepatitis: Results of an open-label preliminary trial. Am J Gastroenterol 1995;90:771-6.

6. Pratt DS, Flavin DP, Kaplan MM. The successful treatment of autoimmune hepatitis with 6-mercaptopurine after failure with azathioprine. Gastroenterology 1996;110:271-4.

7. Kanzler S, Gerken G, Dienes HP, Meyer zum Buschenfelde KH, Lohse AW. Cyclophosphamide as alternative immunosuppressive therapy for autoimmune hepatitis - report of three cases. Z Gastroenterol 1997;35:571-578.

8. Burak KW, Urbanski SJ, Swain MG. Successful treatment of refractory type 1 autoimmune hepatitis with methotrexate. J Hepatol 1998;29:990-3.

9. Zandieh I, Krygier D, Wong V, et al. The use of budesonide in the treatment of autoimmune hepatitis in Canada. Can J Gastroenterol 2008;22:388-92.

10. Richardson PD, James PD, Ryder SD. Mycophenolate mofetil for maintenance of remission in autoimmune hepatitis in patients resistant to or intolerant of azathioprine. J Hepatol 2000;33:371-5.

11. Devlin SM, Swain MG, Urbanski SJ, Burak KW. Mycophenolate mofetil for the treatment of autoimmune hepatitis in patients refractory to standard therapy. Can J Gastroenterol 2004;18:321-6.

12. McLaughlin P, White CA, Grillo-Lopez AJ, Maloney DG. Clinical status and optimal use of rituximab for B-cell lymphomas. Oncology (Williston Park) 1998;12:1763-9.
Specifically, rituximab appears to be a safe and effective second-line therapy for AIH patients who experience treatment failure following prednisone and AZA.

The recent updated American Association for the Study of Liver Diseases guidelines for AIH have suggested that MMF is the "most promising" second-line agent for treatment failures (3). In fact, both of our screen failures were later successfully treated with MMF. However, intolerance to MMF is common and some patients, especially those who are truly refractory to prednisone and AZA, will not experience normalized liver enzyme levels with MMF treatment (3). One subject in our trial was also intolerant to MMF and one subject had failed a one-year trial of MMF before successfully being treated with rituximab. Therefore, rituximab should be considered as an option for $\mathrm{AIH}$ patients with treatment failure who cannot tolerate or who have contraindications to alternative immunosuppressive therapies.

Rituximab was safe, well tolerated and resulted in biochemical and histological improvement in subjects with refractory AIH. These results support further investigation of rituximab as a treatment for $\mathrm{AIH}$.

AUTHOR CONTRIBUTIONS: Guarantor of the article: Kelly W Burak (KWB). Specific author contributions: Study planning (KWB, RPM, MGS, SSL); Conducting the study: study visits (KWB, MGS, SSL, AIA, CSC, RPM), reviewing histopathology (SJU), performing FOXP3 immunohistochemistry (MGS, TSG); Data collection and interpretation (KWB); Drafting manuscript (KWB, RPM). All authors approved the final version of this manuscript.

FINANCIAL SUPPORT: Genentech Inc (South San Francisco, California, USA) provided financial support for this investigator-initiated clinical trial. Robert P Myers has received salary support from the Canadian Institutes of Health Research and Alberta Innovates - Health Solutions.

DISCLOSURES: Robert P Myers has received consulting fees from Genentech, Inc.
13. Cohen SB, Emery P, Greenwald MW, et al. Rituximab for rheumatoid arthritis refractory to anti-tumor necrosis factor therapy: esults of a multicenter, randomized, double-blind, placebocontrolled, phase III trial evaluating primary efficacy and safety at twenty-four weeks. Arthritis Rheum 2006;54:2793-806.

14. Barcellini W, Zanella A. Rituximab therapy for autoimmune haematological diseases. Eur J Intern Med 2011;22:220-9.

15. Carr DR, Heffernan MP. Innovative uses of rituximab in dermatology. Dermatol Clin 2010;28:547-57.

16. Myers RP SA, Swain MG, Lee SS, Shaheen AAM, Burak KW. $B$ cell depletion with rituximab in patients with primary biliary cirrhosis refractory to ursodeoxycholic acid. Am J Gastroenterol 2013 (In press).

17. Tsuda M, Moritoki Y, Lian ZX, et al. Biochemical and immunological effects of rituximab in primary biliary cirrhosis patients with an incomplete response to ursodeoxycholic acid. Hepatology 2012:55:512-21.

18. Breedveld F, Agarwal S, Yin M, et al. Rituximab pharmacokinetics in patients with rheumatoid arthritis: B-cell levels do not correlate with clinical response. J Clin Pharmacol 2007;47:1119-28.

19. Townsend MJ, Monroe JG, Chan AC. B-cell targeted therapies in human autoimmune diseases: An updated perspective. Immunol Rev 2010;237:264-83.

20. Liossis SN, Sfikakis PP. Rituximab-induced B cell depletion in autoimmune diseases: Potential effects on T cells. Clin Immunol 2008;127:280-5.

21. Alvarez F, Berg PA, Bianchi FB, et al. International Autoimmune Hepatitis Group Report: Review of criteria for diagnosis of autoimmune hepatitis. J Hepatol 1999;31:929-38.

22. Fervenza FC, Cosio FG, Erickson SB, et al. Rituximab treatment of idiopathic membranous nephropathy. Kidney Int 2008;73:117-25.

23. Batts KP, Ludwig J. Chronic hepatitis. An update on terminology and reporting. Am J Surg Pathol 1995;19:1409-17. 
24. Xu D, Fu J, Jin L, et al. Circulating and liver resident $\mathrm{CD} 4^{+} \mathrm{CD} 25^{+}$ regulatory $\mathrm{T}$ cells actively influence the antiviral immune response and disease progression in patients with hepatitis B. J Immunol 2006;177:739-47

25. Valko PO, Bassetti CL, Bloch KE, Held U, Baumann CR. Validation of the fatigue severity scale in a Swiss cohort. Sleep 2008;31:1601-7.

26. Afif W, Loftus EV Jr, Faubion WA, et al. Clinical utility of measuring infliximab and human anti-chimeric antibody concentrations in patients with inflammatory bowel disease. Am J Gastroenterol 2010;105:1133-9.

27. Santos ES, Arosemena LR, Raez LE, O'Brien C, Regev A. Successful treatment of autoimmune hepatitis and idiopathic thrombocytopenic purpura with the monoclonal antibody, rituximab: Case report and review of literature. Liver Int 2006;26:625-9.

28. Evans JT, Shepard MM, Oates JC, Self SE, Reuben A. Rituximab-responsive cryoglobulinemic glomerulonephritis in a patient with autoimmune hepatitis. J Clin Gastroenterol 2008;42:862-3.

29. Barth E, Clawson J. A case of autoimmune hepatitis treated with rituximab. Case Rep Gastroenterol 2010;4:502-9.

30. Ferri S, Longhi MS, De Molo C, et al. A multifaceted imbalance of $T$ cells with regulatory function characterizes type 1 autoimmune hepatitis. Hepatology 2010;52:999-1007.

31. Longhi MS, Hussain MJ, Mitry RR, et al. Functional study of $\mathrm{CD} 4^{+} \mathrm{CD} 25^{+}$regulatory T cells in health and autoimmune hepatitis. J Immunol 2006;176:4484-91.

32. Kessel A, Rosner I, Toubi E. Rituximab: Beyond simple B cell depletion. Clin Rev Allergy Immunol 2008;34:74-9.
33. Stasi R, Cooper N, Del Poeta G, et al. Analysis of regulatory T-cell changes in patients with idiopathic thrombocytopenic purpura receiving $\mathrm{B}$ cell-depleting therapy with rituximab.

Blood 2008;112:1147-50.

34. Sfikakis PP, Souliotis VL, Fragiadaki KG, Moutsopoulos HM, Boletis JN, Theofilopoulos AN. Increased expression of the FoxP3 functional marker of regulatory $\mathrm{T}$ cells following $\mathrm{B}$ cell depletion with rituximab in patients with lupus nephritis. Clin Immunol 2007;123:66-73.

35. Feuchtenberger M, Muller S, Roll P, et al. Frequency of regulatory $T$ cells is not affected by transient $B$ cell depletion using anti-CD20 antibodies in rheumatoid arthritis. Open Rheumatol J 2008;2:81-8.

36. Koyabu M, Uchida K, Miyoshi H, et al. Analysis of regulatory T cells and IgG4-positive plasma cells among patients of IgG4-related sclerosing cholangitis and autoimmune liver diseases. J Gastroenterol 2010;45:732-41.

37. Tacke F, Zimmermann HW, Berres ML, Trautwein C, Wasmuth HE. Serum chemokine receptor CXCR3 ligands are associated with progression, organ dysfunction and complications of chronic liver diseases. Liver Int 2011;31:840-9.

38. Nishioji K, Okanoue T, Itoh Y, et al. Increase of chemokine interferon-inducible protein-10 (IP-10) in the serum of patients with autoimmune liver diseases and increase of its mRNA expression in hepatocytes. Clin Exp Immunol 2001;123:271-9.

39. Nagayama K, Enomoto N, Miyasaka Y, et al. Overexpression of interferon gamma-inducible protein 10 in the liver of patients with type I autoimmune hepatitis identified by suppression subtractive hybridization. Am J Gastroenterol 2001;96:2211-7. 


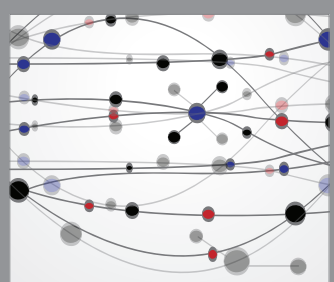

The Scientific World Journal
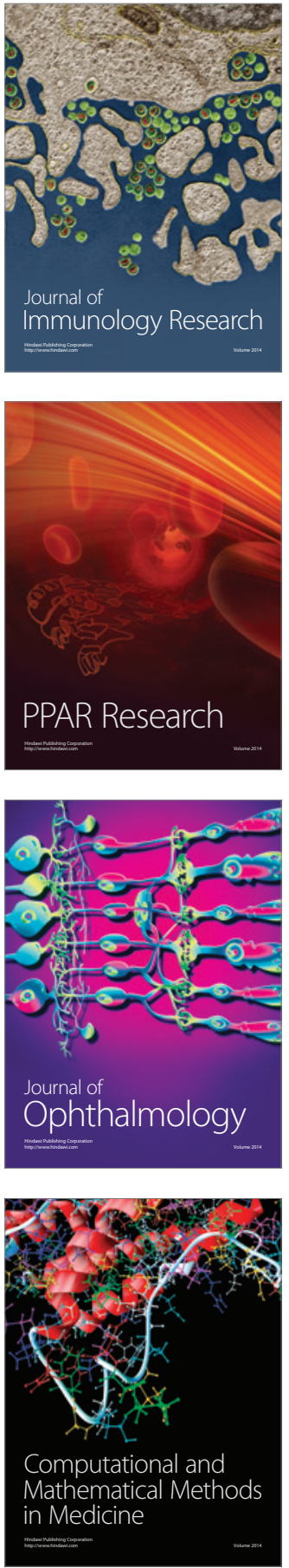

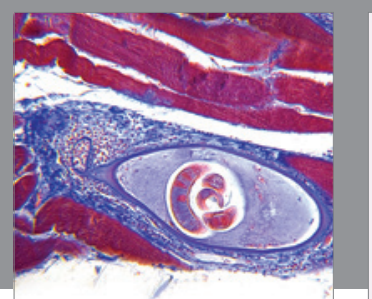

Gastroenterology Research and Practice

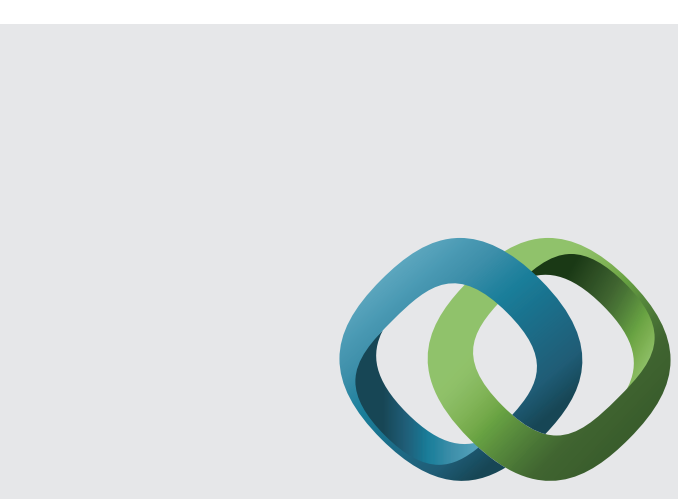

\section{Hindawi}

Submit your manuscripts at

http://www.hindawi.com
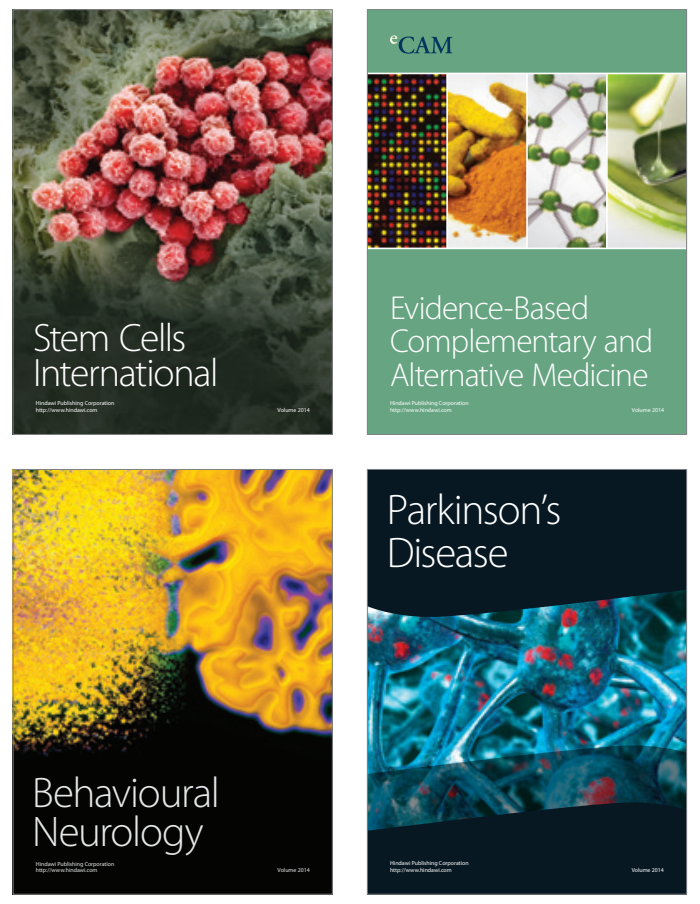
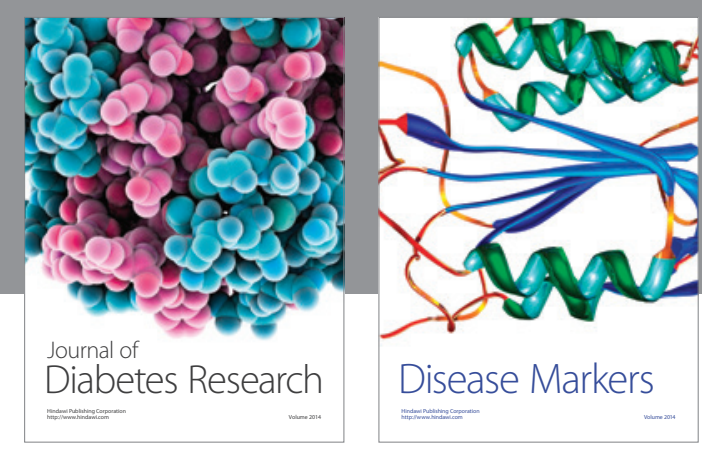

Disease Markers
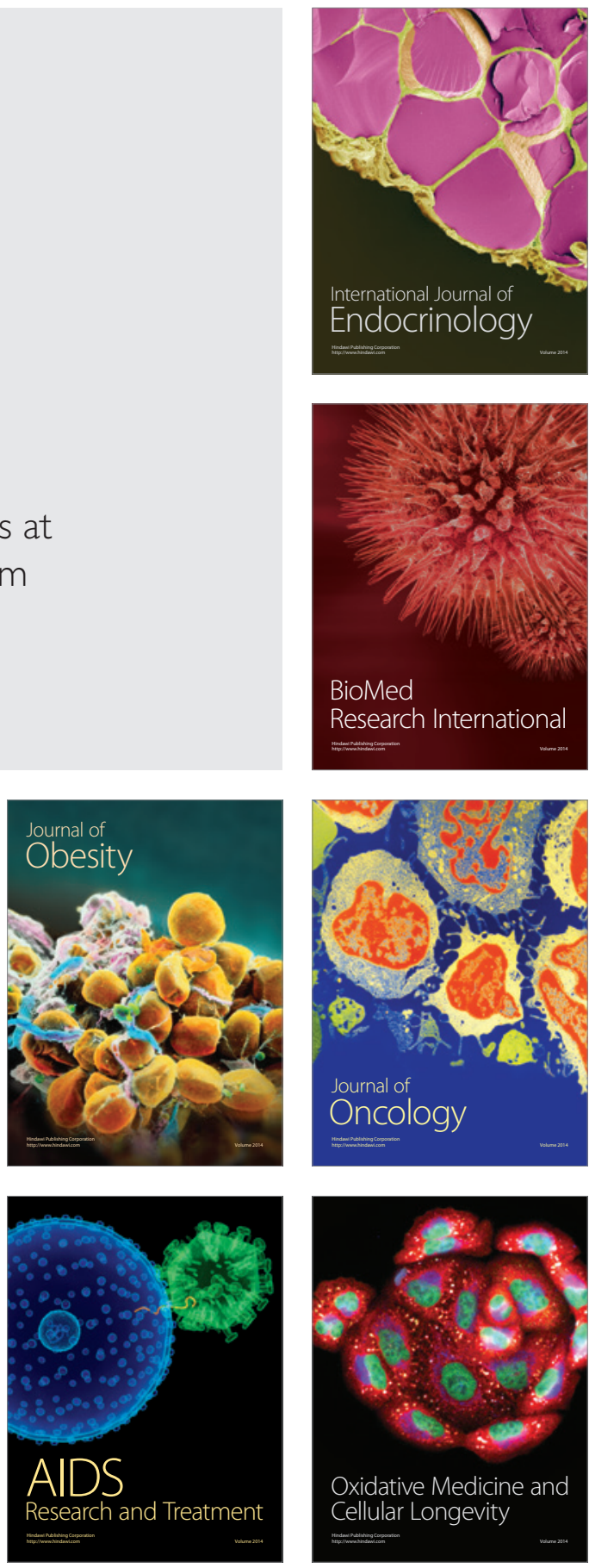